\title{
Morphological and anatomical characters of the spermoderm of certain taxa of the tribe Solaneae (Solanaceae)
}

\author{
Abd El-Salam Al-Nowaihi* \\ and \\ Magdy M. Mourad \\ Botany Department, Faculty of Science, \\ Ain Shams university. \\ Cairo, Egypt \\ * E-mail: abdelsalamalnowaihi@hotmail.com
}

Al-Nowaihi A. S. and Mourad M. M. 1999. Morphological and anatomical characters of the spermoderm of certain taxa of the tribe Solaneae (Solanaceae). Taeckholmia 19 (2): 157-181.

The morphological and anatomical characters of the spermoderm of 49 native and foreign taxa in Wettstein's tribe Solaneae were investigated for their delimitation as well as for a speculation of their phylogenetic status. The observations culminated into the suggestion of an identificatory key. Taxonomic changes including transference (re-allocation) and addition were done for some taxa. Nomenclatural amendments for some other taxa were suggested and a new species, Atropa lutea, has been reached at. The phylogenetic status of the studied taxa was speculated relying on the number of the spermoderm layers. Multi-layered spermoderm was considered less advanced than the few-layered one.

Key words: Solanaceae, Solaneae, spermoderm anatomy, spermoderm morphology.

\section{Introduction}

Only over the latest few years have seed data been progressively studied by SEM for finer details of the surface micro-characters. Together with macro-morphology and seed-coat anatomy all proved their applicability in the interpretation of several taxonomic and phylogenetic queries. To cite but a few literature, one can refer to the work of Wojciechowska (1972), Dilcher (1974), Gunn and Gaffney (1974), Henderson (1974), Corner (1976), Sharma et al., (1977), Whalen (1979 a, b), Wilkinson (1980), Barthlott (1981, 1984), Edmonds (1983), Farooqui (1983), Farooqui and Bahadur (1984, 1985), and Preisner (1985).

As regards the Solanaceae, most of the earlier anatomical investigations on the testa layers and/or its exomorphic pecularities were investigated by LM (West, 1866; Souégés, 1907; Dnyansagar and Cooper, 1960; Czaja, 1963; Saxena and Singh, 1969; Corner, 1976; Rick, 1978; and several others). Although these studies gave valuable information on the subject yet, and as Jha and Pandy (1989) pointed out, few taxonomists had investigated such characters by SEM. Furthermore, and so far as the present authors are aware no attention has been previously paid to the anatomical characters of the spermoderm as being delimitative. With this in mind, this work was undertaken for more

Received 30 June 1999. Revision accepted 27 November 1999. 
accurate identification of certain taxa of the tribe Solaneae as well as for a speculation of their phylogenetic status.

\section{Material and methods}

Our material represents 49 native and foreign taxa belonging to Wettstein's tribe Solaneae (Table 1). The general features of the spermoderm were studied by light stereomicroscope and M5 scanning electron microscope Jeol JSM 35 C SEM working at an accelerating voltage of $20 \mathrm{kv}$. For anatomical investigations the seeds were soaked in water for $12 \mathrm{hrs}$, embedded in paraffin wax microtomed at 12-15 $\mu$, dehydrated and stained with safranin and light green according to the conventional methods (Johansen, 1940). Drawings were made at bench level by a Camera Lucida.

\section{Results and discussion}

\section{A. Macro-features of the Spermoderm (Table 1)}

So far as the present data are concerned, the seed shape shows consistency at both the infra-specific level (cultivars of both Capsicum frutescens and Lycopersicon esculentum) and at the interspecific level (Physalis spp. and Withania spp.). At the generic level the seeds of Solanum spp.exhibit wide spectrum of shape, thus Souégés(1907), Wojciechowska (1971-1972) and Gunn and Gaffney (1974) relied on it, with other characters, in the delimitation of some taxa of the Solanaceae.

As regards the colour, the seeds exhibit various grades between yellow and brown. Although this character was keyed by some earlier workers for some solanaceous taxa (Isely, 1947; Wojciechowska, 1972 and Whalen,1979 a, b), yet the present authors tend to insert it among the weak characters because its expression in a floral organ, is governed by i) the availability to the plant of the aluminium ions in the soil, and ii) the $\mathrm{pH}$ of cell sap; both determining the phenolic compounds formed. The latter give its various degrees from the beginning of maturation to the complete senescence. features.

Perhaps the hilar characteristics (Plate 1) are the most impressive of the general

In this work two aspects of the hilum are studied; the hilar topography viz. levelling relative to the adjacent epidermal cells and the appearance of the latter, and the hilar aperture.

Four cases of topography and two cases of aperture are recorded.

i) As regards topography:

$\mathrm{H}_{1}=$ Hilum sunken with the surrounding epidermal cells arched (ridged).

$\mathrm{H}_{2}=$ Hilum sunken with the surrounding epidermal cells at a level.

$\mathrm{H}_{3}=$ Hilum elevated with the surrounding epidermal cells at a level.

$\mathrm{H}_{4}=$ Hilum at a level, ridges lacking.

ii) As regards the aperture it is either rounded or slit-like. 

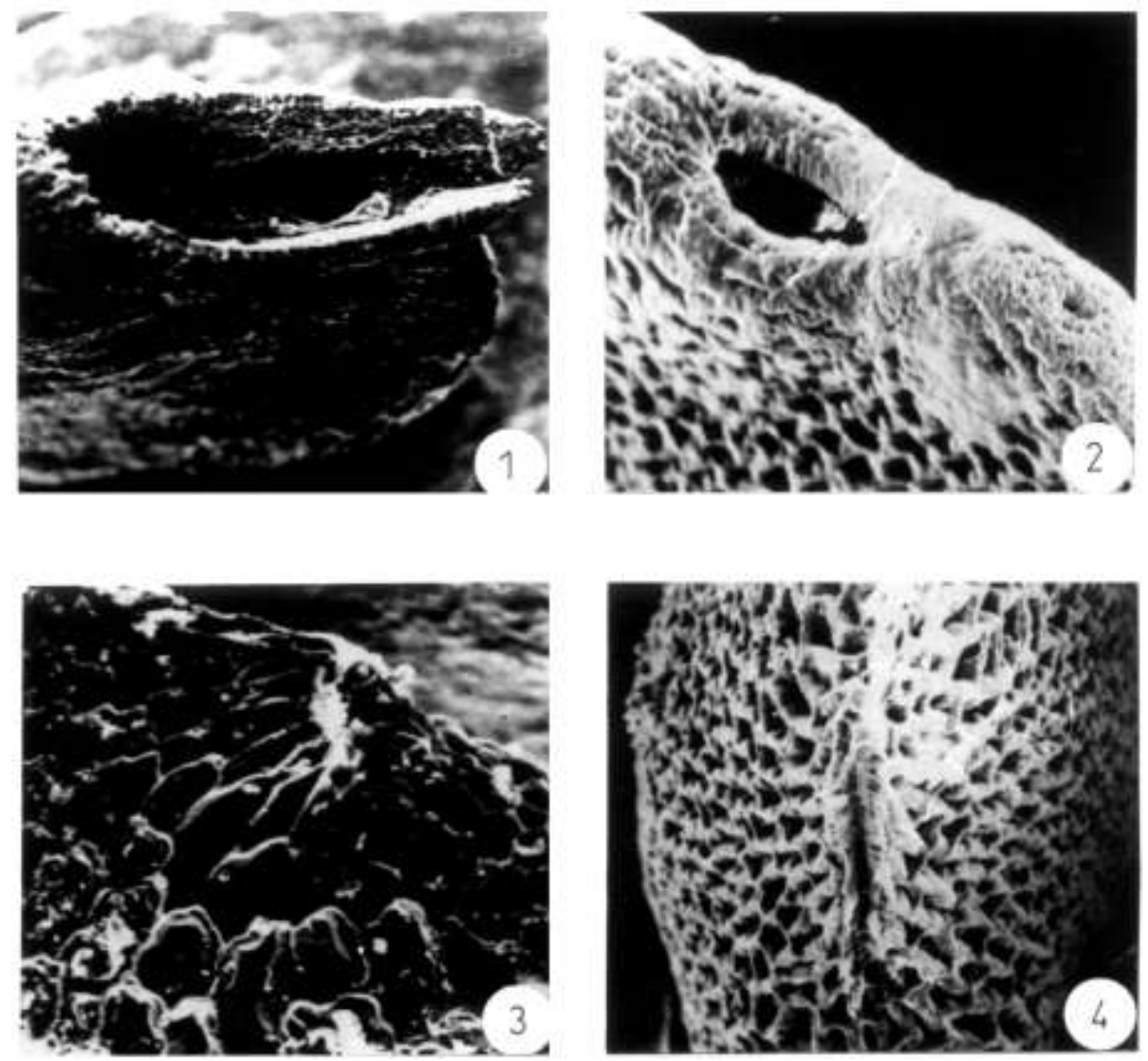

Plate 1- SEM micrographs of hilar shape and topography. Fig.1 Capsicum frutescens (H1-type) x50, Fig.2.Solanum macrocarpon (H2-type) x200, Fig.3.Atropa belladonna (H3-type)x200, Fig.4. Solanum nigrum (H4-type)x100. 
Table (1) The Morphological Aspects of the Spermoderm

\begin{tabular}{|c|c|c|c|c|c|c|c|}
\hline \multirow{3}{*}{ Aspects } & \multicolumn{2}{|c|}{ LM } & \multicolumn{5}{|c|}{ SEM } \\
\hline & \multirow[b]{2}{*}{ Shape } & \multirow[b]{2}{*}{ Colour } & \multicolumn{2}{|c|}{ Hilum } & \multicolumn{3}{|c|}{ Surface View of the Spermoderm } \\
\hline & & & Shape & $\begin{array}{l}\text { Topogr } \\
\text { aphy }\end{array}$ & $\begin{array}{l}\text { Anticlinal wall } \\
\text { Reticulation }\end{array}$ & $\begin{array}{c}\text { 1ry } \\
\text { wall }\end{array}$ & Periclinal wall \\
\hline 1- Atropa belladonna L. & $\begin{array}{l}\text { Reniform / } \\
\text { Subglobose }\end{array}$ & Brown & Rounded & $\mathrm{H}_{3}$ & Lobed & + & Gl.deeplyCv \\
\hline 2- A. belladonna var. lutea Doll. & Subglabose & Brown & Rounded & $\mathrm{H}_{4}$ & Straight & + & Gl.deeplyCv \\
\hline 3- Capsicum annuиm $\mathrm{L}$. & $\begin{array}{l}\text { Reniform } \\
\text { with tapering end }\end{array}$ & Yellow & Slit Like & $\mathrm{H}_{1}$ & Lobed-micropap. & - & Gl.- $\mathrm{Cv}$ \\
\hline 4- C. frutescens L. cv. California Wonder. & $\begin{array}{l}\text { Reniform } \\
\text { with tapering end }\end{array}$ & Yellowish Red & Slit Like & $\mathrm{H}_{1}$ & Slight-Undulate & - & Gl.-Cv \\
\hline 5- C. frutescens 1. cv. Early Jalpino. & $\begin{array}{c}\text { Reniform with } \\
\text { tapering end }\end{array}$ & Yellowish Red & Slit Like & $\mathrm{H}_{1}$ & Slight-Undulate & - & Gl.-Cv \\
\hline 6- C. frutescens L. cv. Elpaso & $\begin{array}{l}\text { Reniform with } \\
\text { tapering end }\end{array}$ & Yellowish Red & Slit Like & $\mathrm{H}_{1}$ & Slight-Undulate & - & Gl.-Cv \\
\hline 7- C. frutescens L. cv. Long Red Cayenne. & $\begin{array}{l}\text { Reniform with } \\
\text { tapering end }\end{array}$ & Yellowish Red & Slit Like & $\mathrm{H}_{1}$ & Slight-Undulate & - & Gl.-Cv \\
\hline 8- Cyphomandra betacea (Cav.) Sendt & Orbicular & Pale Yellow & Rounded & $\mathrm{H}_{2}$ & Lobed Hairy & - & - \\
\hline 9- Hyoscyamus aureus L. & Oval & Brown & Rounded & $\mathrm{H}_{4}$ & Lobed & - & Gl.-Cv \\
\hline 10- H. boveanus (Dun.) Asch. \& Schweinf. & Oval & Brown & Rounded & $\mathrm{H}_{4}$ & Lobed & - & Gl.-Cv \\
\hline 11-H. desertorum Asch Ex Bioss. & Oval & Pale Brown & Rounded & $\mathrm{H}_{4}$ & Lobed & - & Gl.-Cv \\
\hline 12-H. munticus L. & Oval & Brown & Rounded & $\mathrm{H}_{4}$ & Lobed & - & Gl.-Cv \\
\hline 13-H. niger L. & Oval & Brown & Rounded & $\mathrm{H}_{4}$ & Slight Undulate & - & Gl.-Cv \\
\hline 14- Lycium chinense Mill. & Orbicular & Yellowish & Rounded & $\mathrm{H}_{4}$ & Lobed & + & Gl.-deeply Cv \\
\hline 15- L. shawii Roem. Et Sch. & Triangular & Brown & Rounded & $\mathrm{H}_{2}$ & Lobed-invaginat & - & Gl.-deeply CV \\
\hline 16- Lycopersicon esculentum Mill. & Oval/tapering end & Straw Yellow & Slit-Like & $\mathrm{H}_{4}$ & Lobed-Hairy & - & - \\
\hline 17- L. esculentum cv. Bakmor B. & Oval & Pale Rose & Slit-Like & $\mathrm{H}_{4}$ & Lobed-Hairy & - & - \\
\hline 18-L. esculentum cv. Strain B. & Oval & Pearl Gray & Slit-Like & $\mathrm{H}_{4}$ & Lobed-Hairy & - & - \\
\hline 19- L. esculentum cv. UC 82. & Oval & Rose & Slit Like & $\mathrm{H}_{4}$ & Lobed-Hairy & - & - \\
\hline 20- L. esculentum cv. VFN 8. & Oval & Pale Rose & Slit Like & $\mathrm{H}_{4}$ & Lobed-Hairy & - & - \\
\hline 21- L. esculentum var. pyriforme Alef. & Oval & Tawny Yellow & Slit Like & $\mathrm{H}_{4}$ & $\begin{array}{c}\text { Slight-undulate- } \\
\text { Hairy }\end{array}$ & - & - \\
\hline 22- Mandragora officinarum L. & Reniform & Pale Yellow & Rounded & $\mathrm{H}_{4}$ & Lobed-micropap. & - & Microret.-Cv \\
\hline 23- Physalis alkekengi L. & Reniform & Yellow & Rounded & $\mathrm{H}_{2}$ & Lobed & + & Gl.-deeply Cv \\
\hline 24- P. angulata $\mathrm{L}$. & Reniform & Brown & Slit Like & $\mathrm{H}_{4}$ & Lobed-int. & - & Gl.-deeply CV \\
\hline 25- P. ixocarpa Brot. ex Hornem. & Reniform & Straw Yellow & Rounded & $\mathrm{H}_{2}$ & Lobed & + & Gl.-deeply CV \\
\hline 26-P. peraviana L. & Pear/Reniform & Straw Yellow & Rounded & $\mathrm{H}_{2}$ & Lobed & + & Gl.-deeply CV \\
\hline 27- P. prainosa L. & Reniform & Yellow & Rounded & $\mathrm{H}_{2}$ & Lobed & + & Gl.-deeply Cv \\
\hline 28-Scopalia lurida(Link\&Otto.) Dun. & Pear/Reniform & Brown & Rounded & $\mathrm{H}_{4}$ & Lobed & + & Gl.-deeply Cv \\
\hline 29-S. physaloides Dun in DC. & Pear/Reniform & Yellowish Brown & Rounded & $\mathrm{H}_{4}$ & Straight & + & Gl.-frat \\
\hline 30-Solanum aviculare G.Farster. & Oval & Pale Brown & Rounded & $\mathrm{H}_{2}$ & Lobed & - & $*$ \\
\hline 31-S. citrullifolium A.Br. & Oval & Dark Brown & Rounded & $\mathrm{H}_{2}$ & Lobed & + & Str.deeply CV \\
\hline 32- S. cornutum Lam. & Reniform & Dark Brown & Rounded & $\mathrm{H}_{2}$ & Lobed-micropap. & - & Gl.-flat \\
\hline 33-S. dulcamara L. & Oval & Yellow & Slit Like & $\mathrm{H}_{4}$ & Lobed-micropap. & - & Gl.-Cv \\
\hline 34- S. forsskaolii Ky ex Dun. & $\begin{array}{l}\text { Orbicular/deep } \\
\text { furrow }\end{array}$ & Dark Brown & Rounded & $\mathrm{H}_{2}$ & Straight & - & Gl.-Cv \\
\hline 35-S. incanum L. & Orbicular/Reniform & Dark-Brown & Rounded & $\mathrm{H}_{2}$ & Lobed-int. & - & $*$ \\
\hline 36- S. indicum var. aldabranse Linn. & Reniform & Yellowish & Slit Like & $\mathrm{H}_{2}$ & Lobed-micropap. & + & Curled-Cv \\
\hline 37-S. macranthum Dun. & Orbicular & Pale Brown & Rounded & $\mathrm{H}_{2}$ & Lobed-micropap. & + & Curled Cv \\
\hline 38-S. macrocarpon L. & Pear & Straw Yellow & Rounded & $\mathrm{H}_{2}$ & Lobed-int. & - & $*$ \\
\hline 39-S. melongena L. cv. Block Beuty. & Orbicular/Reniform & Pale Yellow & Rounded & $\mathrm{H}_{2}$ & Lobed-int. & - & $*$ \\
\hline
\end{tabular}




\begin{tabular}{|c|c|c|c|c|c|c|c|}
\hline 40- S. melongena cv.Long Purple. & Orbicular/Reniform & Pale Yellow & Rounded & $\mathrm{H}_{2}$ & Lobed-int. & - & $*$ \\
\hline 41-S. melongena cv. Long White & Orbicular/Reniform & Pale Yellow & Rounded & $\mathrm{H}_{2}$ & Lobed-int. & - & $*$ \\
\hline 42-S. nigrum L. & Oval & Yellow & Slit Like & $\mathrm{H}_{4}$ & Lobed-micropap. & - & $*$ \\
\hline 43-S. quitoensis Lam. & Pear/Reniform & Dark Brown & Slit Like & $\mathrm{H}_{2}$ & Slight-pap. & - & $*$ \\
\hline 44-S. seaforthianum Andrews & Pear/Reniform & Brown & Rounded & $\mathrm{H}_{2}$ & $\begin{array}{l}\text { Slight undulate.- } \\
\text { hairy }\end{array}$ & - & - \\
\hline 45- S. sisymbriifolium Lam. & Orbicular/Reniform & Pale Yellow & Rounded & $\mathrm{H}_{2}$ & micropap. & - & Curled-Cv \\
\hline 46- S. villosum (L.) Mill. & Oval & Yellow & Slit-Like & $\mathrm{H}_{4}$ & Lobed-micropap. & - & $*$ \\
\hline 47-S. wrightii Benth. & Oval & Pale Brown & Slit-Like & $\mathrm{H}_{4}$ & Lobed-invaginate & + & Gl.-flat \\
\hline 48- Withania riebeckii Schweing & Reniform & Brown & Slit-Like & $\mathrm{H}_{2}$ & Lobed & + & Gl.-deeply Cv \\
\hline 49- W. somnifera (L.) Dun. & Reniform & Pale Brown & Slit-Like & $\mathrm{H}_{2}$ & Lobed-micropap. & + & Gl.-deeply CV \\
\hline
\end{tabular}

+, Present; - , Absent; Cv , Concave; Gl., Glabrous; int, Intestine ; pap., Papillate ; Str., Striated; * , Ill - defined.

The hilar characteristics seem to be diagnostic at the generic level $\left(\mathrm{H}_{4-}\right.$ Hyoscyamus). Martin \& Barkley (1961), reached at a similar conclusion where they in addition, took into consideration the seed shape and size. At the infra-specific level $\left(\mathrm{H}_{1}\right.$ Capsicum cvs.) the hilar aspect is consistent. In Solanum, some species have the $\mathrm{H}_{2}$-type and some others have the $\mathrm{H}_{4}$ - type. The inconsistency in this genus may be one justification to its heterogeneous nature. External evidence for its heterogenity comes from the numerical study by Al-Nowaihi and Khalifa (1974) on certain members of Solanaceae.

\section{B-SEM of the spermoderm (Plate 2)}

SEM of the epidermal cells clarifies the texture and reticulation of their anticlinal (radial) walls, the appearance of the outer periclinal walls and the persistency of the primary cell walls.

\section{i) Reticulation of the anticlinal walls}

The seed surface reticulation is simple with pentagonal-hexagonal epidermal cells having straight anticlinal walls with normal thickening. This pattern is considered here as the basic type and is recorded in Atropa belladonna var. lutea, Scopolia physaloides and Solanum forsskaolii. In the remainder taxa, such aspect is disturbed through the elongation to various degrees of the anticlinal walls, their thickening, undulation and the appendages they carry, if any. Taking this into consideration the following cases are recorded for the anticlinal walls: Straight papillate (Solanum quitoensis), straight micropapillate (Solanum sisymbriifolium), slight undulate either glabrous (species nos. 4, 5, 6, 7\& 13), or hairy (Lycopersicon esculentum var. pyriforme and Solanum seaforthianum), lobed (species nos..1, 10, 11, 12, 14, 23, 25, 26, 27, 28, 30, 31, \& 48), lobed hairy (species nos .8, 9, 16, $17,18,19 \& 20$ ), lobed micropapillate (species nos. 3, 22, 32, 33, 36, 37, 42, 46 \& 49), lobed with invaginated wall (Lycium shawii and Solanum wrightii) or lobed with intestinelike wall (species nos . 24, 35, 38, 39, $40 \& 41$ ).

\section{ii) Outer periclinal wall (Table 1)}


In the present work the description is confined to the outer wall since the inner one is best studied through the anatomy of the seed coat. The outer wall is lacking in eight taxa. Dnyansagar and Cooper (1960), Czaja (1963), Saxena and Singh (1969) and Mohan (1970) attributed its absence to the transformation of their corresponding cell contents into mucilage during the formation of 'hairs'. Also Czaja (1963) and Farooqui (1983), stated that the hair-like structures are bands of lignified thickenings on the lateral and basal walls of the outer epidermis.

As regards its shape in surface view, it may be flat (Scopolia lurida, and $S$. physaloides; Solanum cornutum and $S$. wrightii), concave (species nos..3, 4, 5, 6, 7, 8, 9, 10, 11, 12, 13 \& 34), concave and curled in Solanum macranthum and S. sisymbriifolium, concave and microreticulate in Mandragora officinarum, deeply concave in species nos..1, 2, 14, 15, 23, 24, 25, 26, 27, 48 \& 49, deeply concave and striate in Solanum citrullifolium and $S$. indicum var. aldabranse and ill-defined in ( species nos..30, 33, 35, 38, 39, 40, 41, 42, 43 \& 46). 

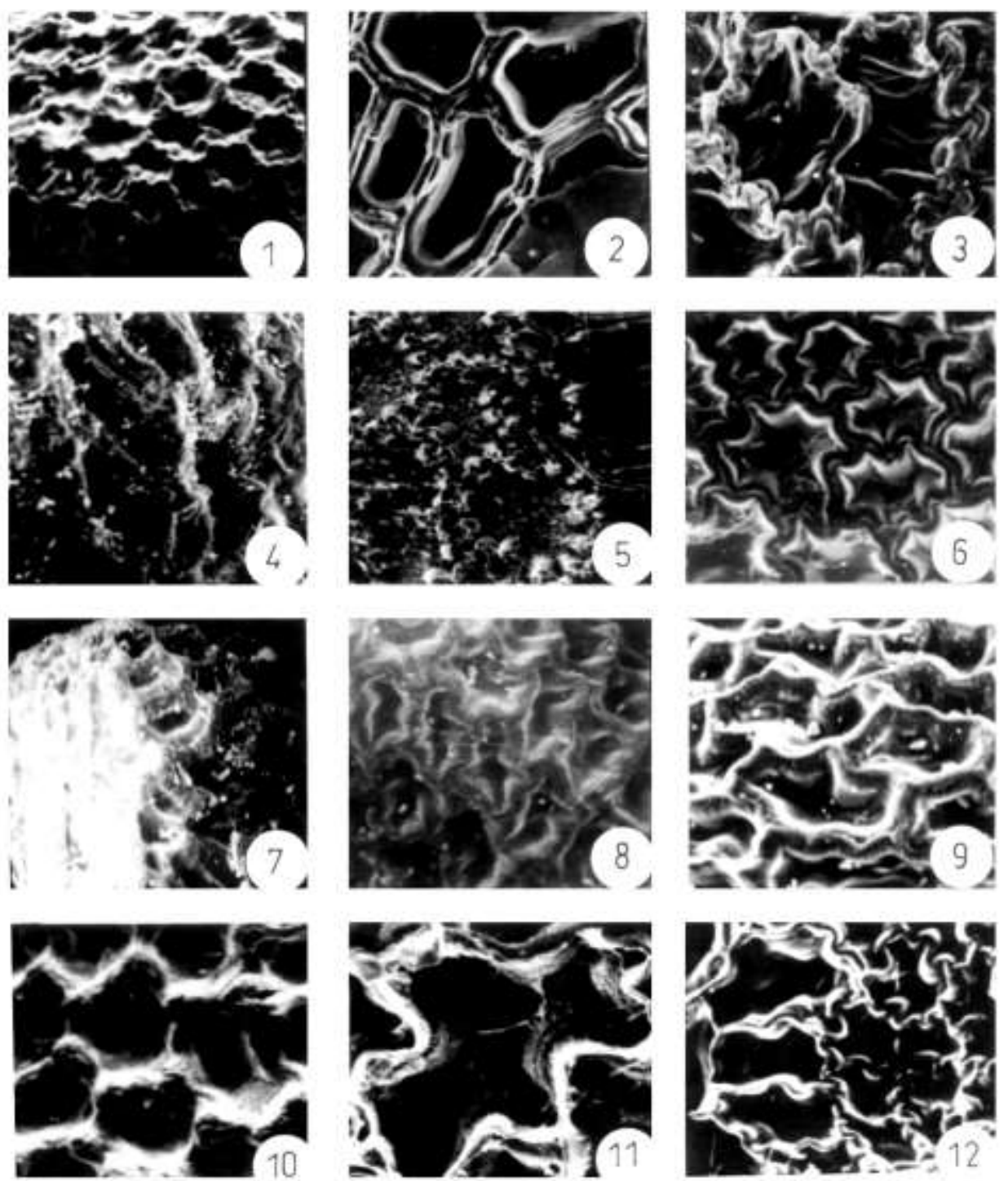

Plate 2- Spermoderm surface under SEM. Fig.1-Atropa belladonna x100, Fig.2- $A$. belladonna var. lutea x200, Fig.3 Capsicum annum x200, Fig.4-C. frutescens cvs. X350, Fig.5-Cyphomandnra betacea x200, Fig.6-Hyoscyamus aureus x200, Fig.7-H. boveanus x500, Fig.8-H. desertorum x200, Fig.9-H. muticus x200, Fig.10-H. niger x200, Fig.11-Lycium chinense x500, Fig.12-L. shawii x200 

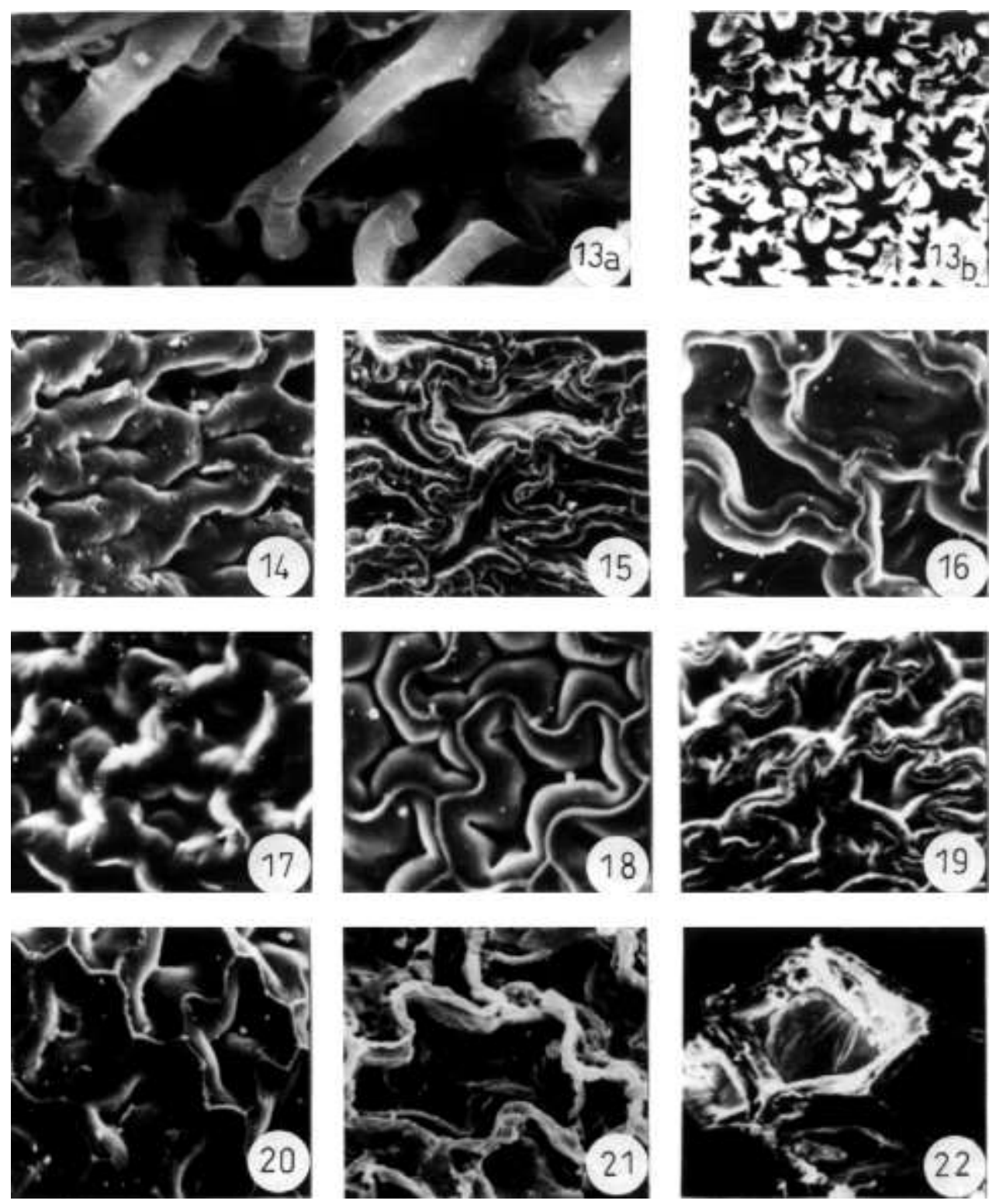

Plate 2- Spermoderm surface under SEM (cont.). Fig.13a- Lycopersicon esculentum, a portion of the coat with hairs x500, Fig.13b- The same glabrous x150, Fig.14- $L$. esculentum var. pyriforme x500, Fig.15-Mandragora officinarum $\times 100$, Fig.16-Physalis alkekengi $\mathrm{x} 200$, Fig.17-P. angulata $\mathrm{x} 200$, Fig.18-P. ixocarpa $\mathrm{x} 200$, Fig.19-P. peruviana x500, Fig.20-P. pruinosa x200, Fig.21- Scopolia lurida x 200, Fig.22-S. physaloides $\mathrm{x}$ 200 

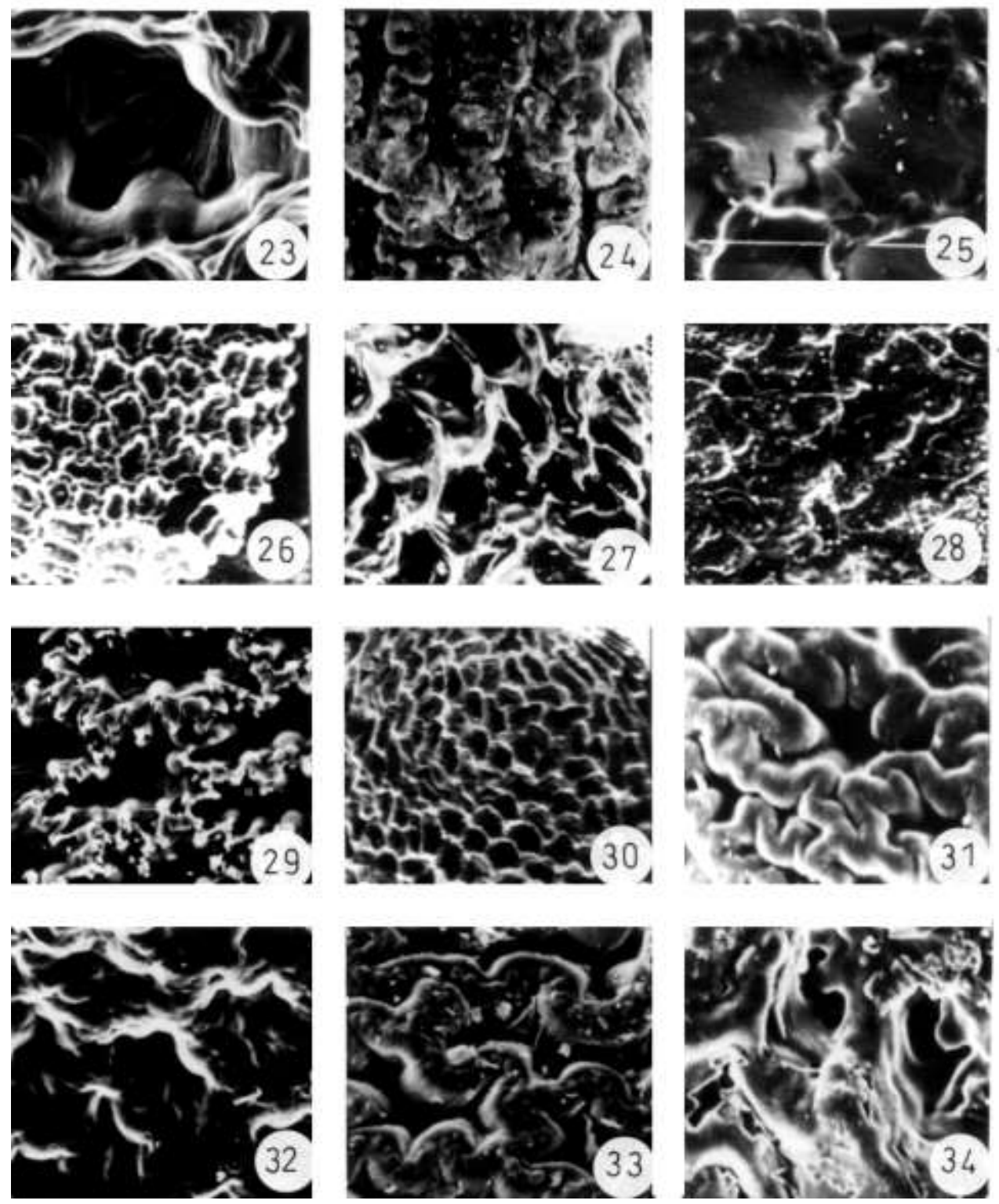

Plate 2- Spermoderm surface under SEM (cont.). Fig.23- Solanum aviculare x100, Fig.24-S. citrullifolium $\times 500$, Fig.25-S. cornutum $\times 550$, Fig.26-S. dulcamara $\times 200$, Fig.27-S. forsskaolii x200, Fig.28-S. incanum x 200, Fig.29- S. indicum var. aldabranse x500, Fig.30- S. macranthum x500, Fig.31-S. macrocarpon x200, Fig.32- S. melongena cvs. X500, Fig. 33-S. nigrum x350, Fig.34- S. quitoensis x200. 

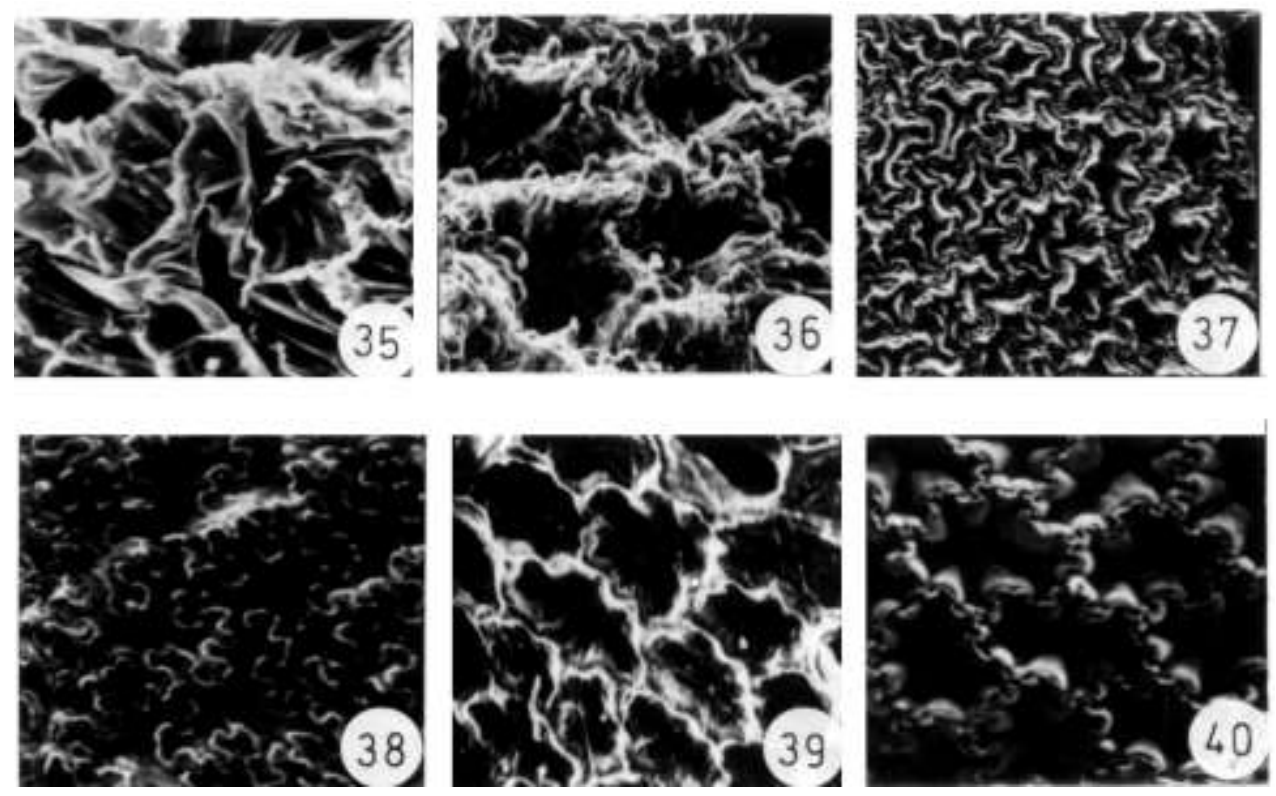

Plate 2- Spermoderm surface under SEM (continued). Fig.35-S. seaforthianum x200, Fig.36-S. sisymbriifolium x200, Fig.37- S. villosum x200, Fig.38-S. wrightii x200, Fig.39- Withania riebeckii $\times 200$, Fig.40- W. somnifera $\times 500$.

Our observations on the outer periclinal wall seem to be diagnostic at both the generic level (Physalis, Withania) and the specific level (Solanum investigated species.). So far as the available literature is concerned, such characters were not considered by earlier workers.

\section{iii) Detection (persistence) of the primary cell wall}

The primary cell wall is undetectable in 32 taxa, detectable in 15 taxa and more or less detectable in the remaining two taxa. Although, no reference has early been done to this character, yet, in the present work, it is considered to be rather diagnostic (cf.. the proposed artificial key).

\section{Spermoderm Anatomy (Plate 3)}

Generally, the seed coat is formed of an outer epidermis, an intermediate parenchymatous zone and inner epidermis forming the endothelium. The intermediate zone may be differentiated into an outer parenchymatous layer forming a hypoderm and an inner hyaline layer consists of more or less compressed cells. (Table 2).

In the present study, the endothelium is absent in Mandragora officinarum, Scopolia lurida and S. physaloides. Where the three layers are present, the following variation patterns are recorded: 
1) Outer epidermis - The shape of the epidermal cells is ill-defined in eight taxa (species nos. 8, 16, 17, 18, 19, 20, $21 \& 44)$. The reasoning put earlier by Hayward (1938), Saxena and Singh (1969) and Mohan (1970) and presented elsewhere in this paper, is that the unclarity is due to the transformation of the outer walls to mucilage during the formation of hairs. In the remainder taxa, the epidermal cells are clearly detected as being radially elongated in 38 taxa, tangentially elongated in eight taxa or tangentially and radially elongated in five taxa. However the different walls of the epidermal cells have the following aspects.

i) Outer periclinal wall - Where the outer periclinal wall is persistent and detectable, the following cases are recorded: straight in 24 taxa, straight to concave in six taxa, deeply concave in Lycium chinense and L. shawii, shallowly-concave in the three cvs. of Solanum melongena, concave in five taxa, deeply invaginated with micropapillae in Solanum sisymbriifolium. Such variation in straightness and concavity is found to be consistent in Capsicum, Lycium, Scopolia and Withania, species, and inconsistent in the investigated Solanum species.

ii) Inner periclinal wall- These are either thin in Solanum quitoensis, thick and even in 25 taxa or comparatively thick with the cell having one-two median papillae in 23 taxa.

iii) Anticlinal (Radial) wall -They are thick in all the taxa studied and the thickening differs as regards to whether it is on the entire length of the wall or only on a part of it. The following cases are recorded: the thickening is to the summit of the wall (23 taxa), the thickening is deposited on 3/4 of the wall or the thickening is half-way (five taxa). Edmonds (1983) argued whether the thickening could be taxonomically effective at the generic, sectional and the specific levels, while Souégés (1907) relied upon the shape of thickening. Here, the thickening is consistent at the generic level (Solanum excluded) as well as effective as a key character.

2) Middle layer -The two zones of the middle layer, viz. the outer parenchymatous and the inner hyaline are recorded in 12 taxa, the outer zone is absent in 13 taxa and both are lacking in the remainder 24 taxa.

3) Inner epidermis (Endothelium) - It is ill-defined in Scopolia lurida, S. physaloides and Mandragora officinarum., it consists of one layer in the other taxa. recorded:

Where the endothelium is persistent and detectable, the following aspects are

i) Shape- Either tangentially flattened in eight taxa, rectangular in 30 taxa or squared in eight taxa.

ii) Thickening- The endothelial cells are either thin (14 taxa) or thick. Where the thickening is recorded it differs in both universality on all the walls or its restriction to some of them. The following patterns are observed.

1. All walls of the endothelial cells are thick (16 taxa).

2. Only the outer periclinal wall is thin (seven taxa).

3. Only the inner periclinal wall is thin (eight taxa).

4. Only the outer periclinal wall is thick (Solanum macrocarpon).

iii) Pigmentation-The endothelium is pigmented in 23 taxa, other taxa lack the pigments. 

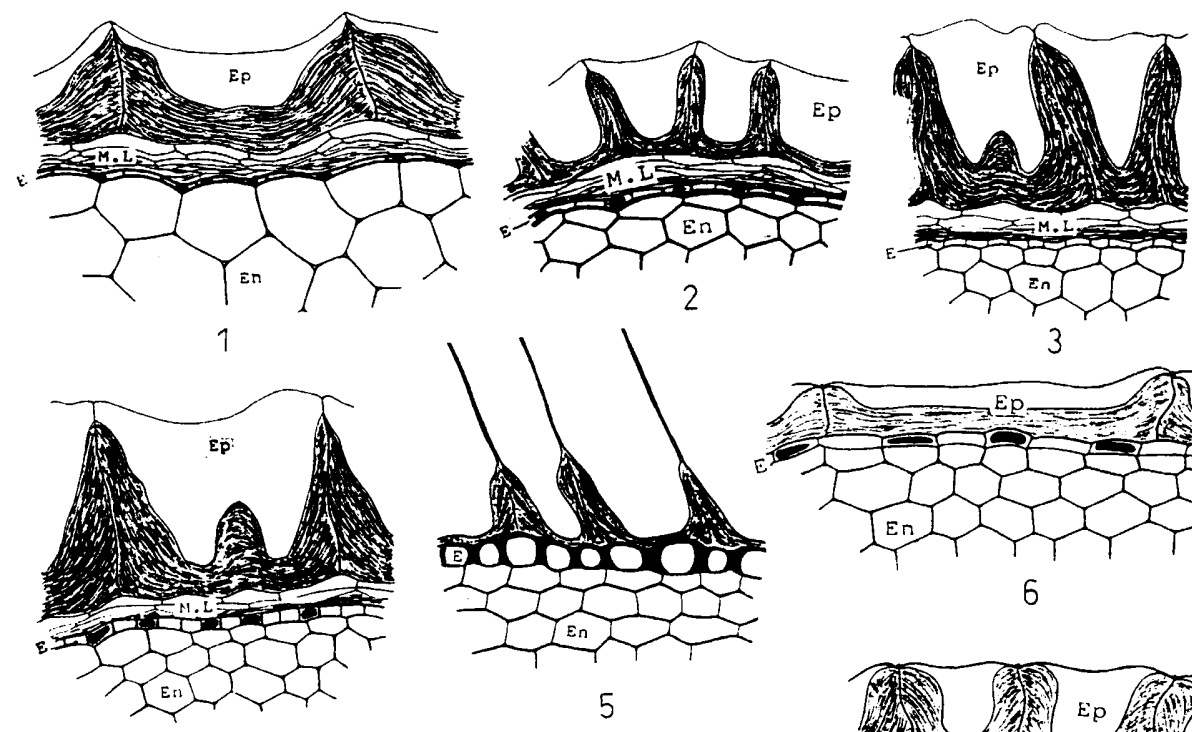

3

4
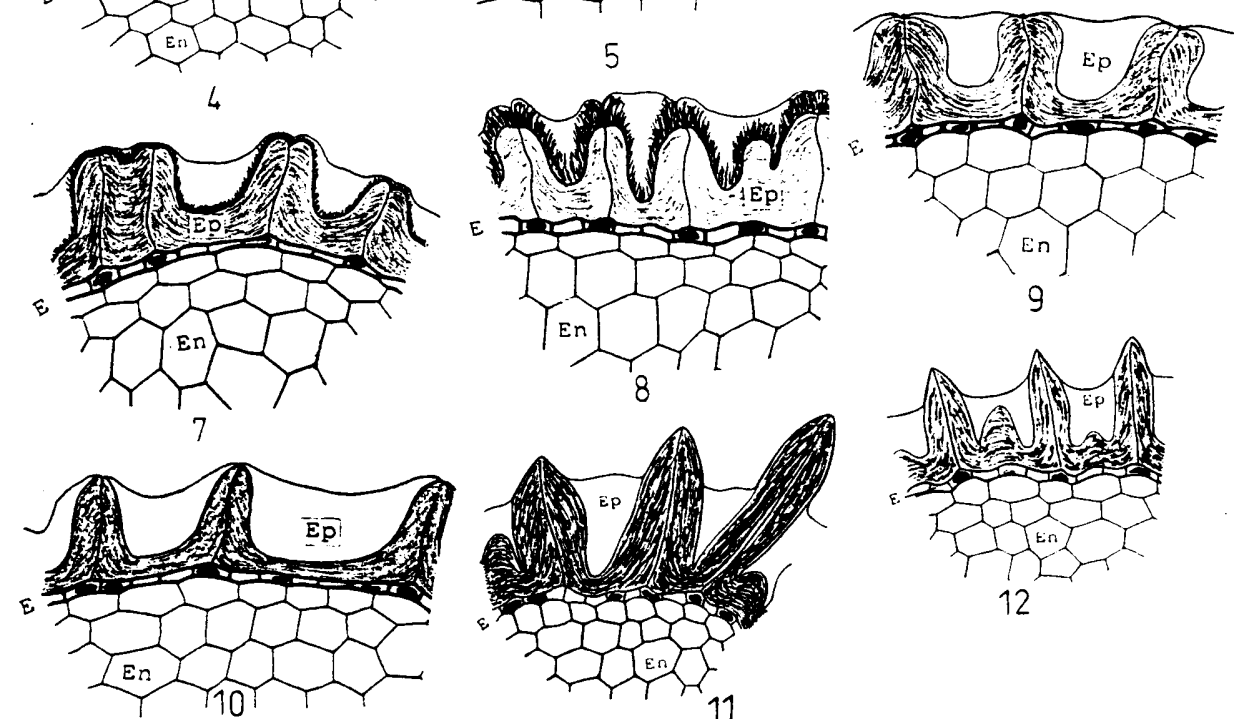

Plate 3- Spermoderm anatomy. Fig.1. Atropa belladonna, Fig.2. A. belladonna var. lutea, Fig.3. Capsicum annuum, Fig.4. C. frutescens cvs., Fig.5. Cyphomandra betacea, Fig.6. Hyoscyamus aureus, Fig.7. H. boveanus, Fig.8. H. desertorum, Fig.9. H. muticus, Fig.10. H. niger, Fig.11. Lycium chinense, Fig.12. L. shawii. $\mathrm{Cu}=\mathrm{Cu}$ ticle; $\mathrm{E}=$ Endosperm; En=Endothecium; Ep=Epidermis; M.L=Middle Layer. 


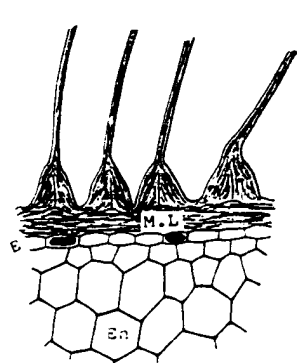

13

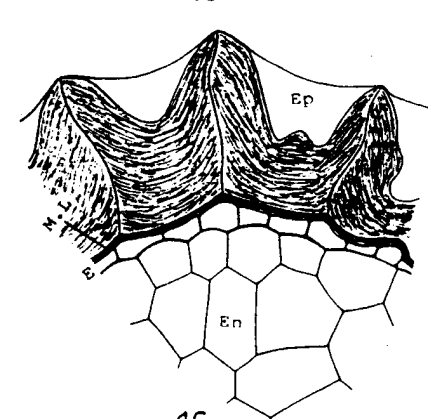

16

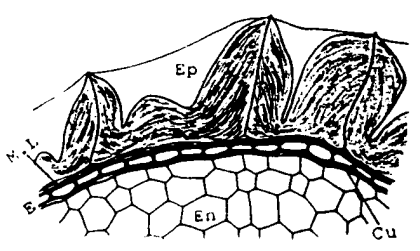

19
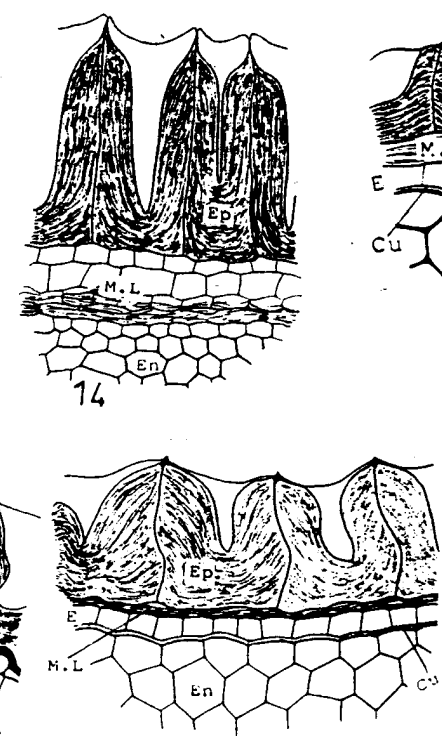

17

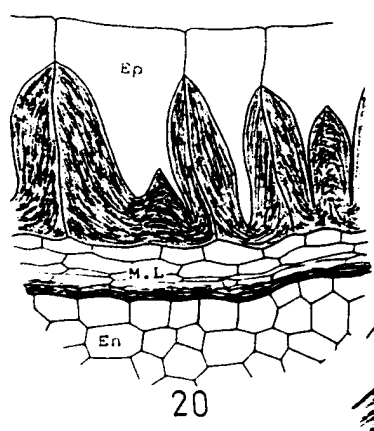

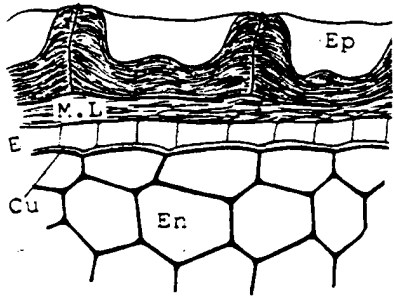

15

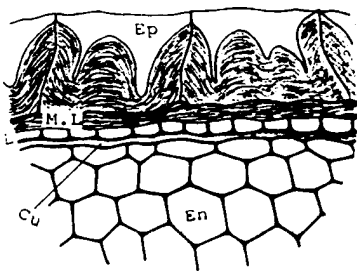

18

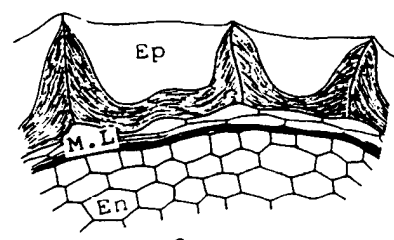

21

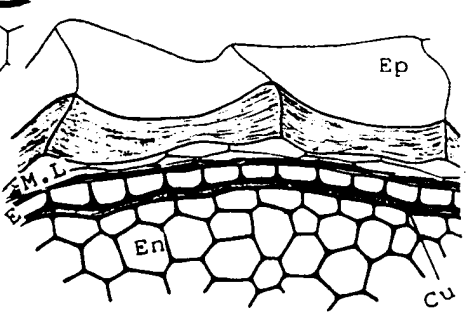

22

Plate 3. Spermoderm anatomy (cont.). Fig.13. Lycopersicon esculentum cvs. and var. pyriforme, Fig.14. Mandragora officinarum, Fig.15. Physalis alkekengi, Fig.16. P. angulata, Fig.17. P. isocarpa, Fig.18. P. peruviana, Fig.19. P. pruinosa, Fig.20. Scopolia lurida, Fig.21. S. physaloides, Fig.22. Solanum aviculare. $\mathrm{Cu}=\mathrm{Cuticle;} \mathrm{E=Endosperm;} \mathrm{En=Endothecium;}$ Ep=Epidermis; M.L=Middle Layer. 


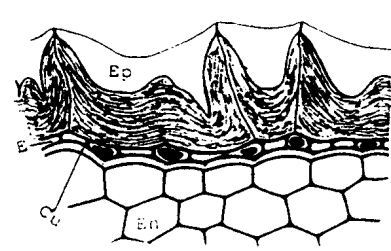

23

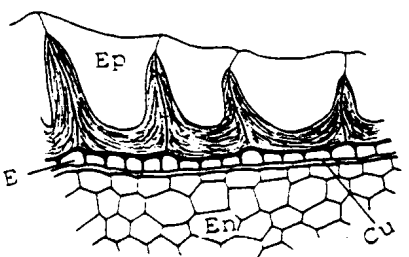

26

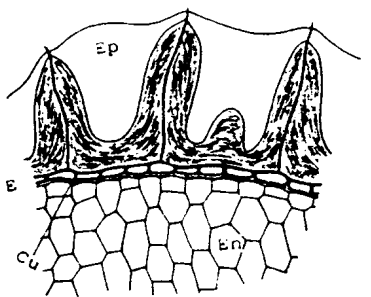

29

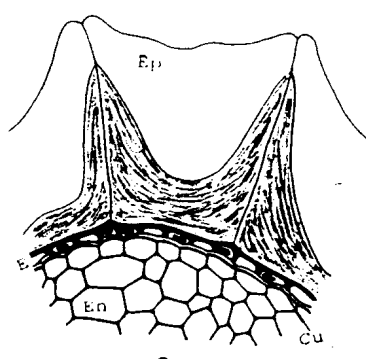

24

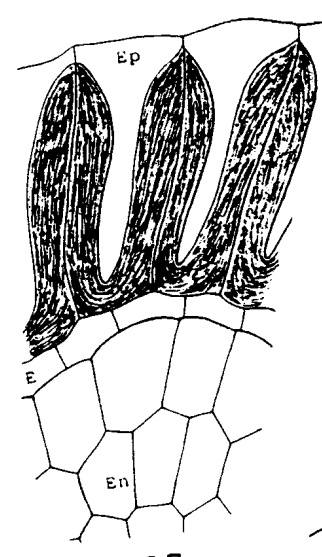

27

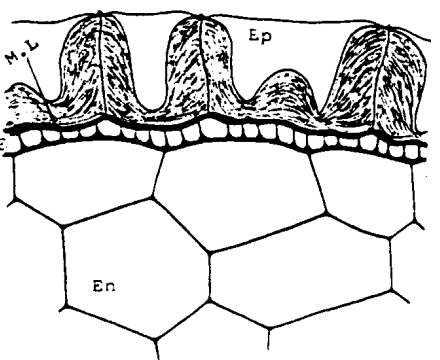

25
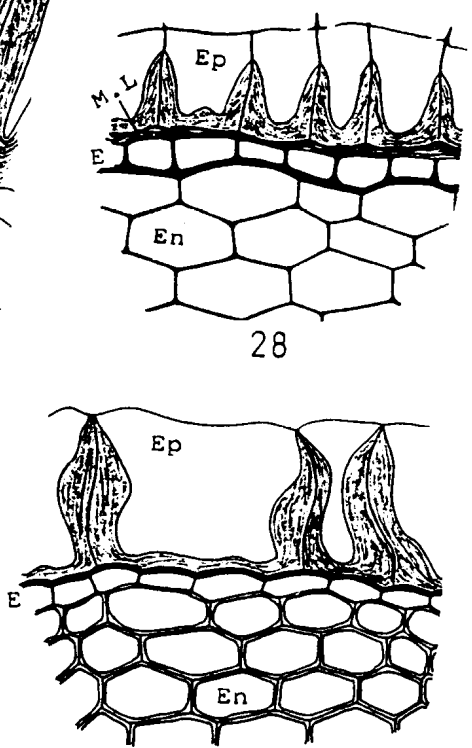

30

Plate 3- Spermoderm anatomy (cont.). Fig.23. S. citrullifolium, Fig.24. S. cornutum. Fig.25. S dulcamara, Fig.26. S. forsskaolii, Fig.27. S. incanum, Fig.28. S. indicum var. aldabranse, Fig.29. S. macranthum, Fig.30. S. macrocarpon. $\mathrm{Cu}=\mathrm{Cuticle;} \mathrm{E}=$ Endosperm; $\mathrm{En}=$ Endothecium; Ep=Epidermis; M.L=Middle Layer. 


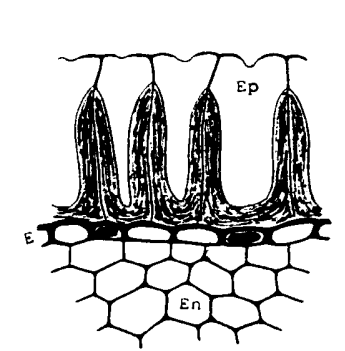

31
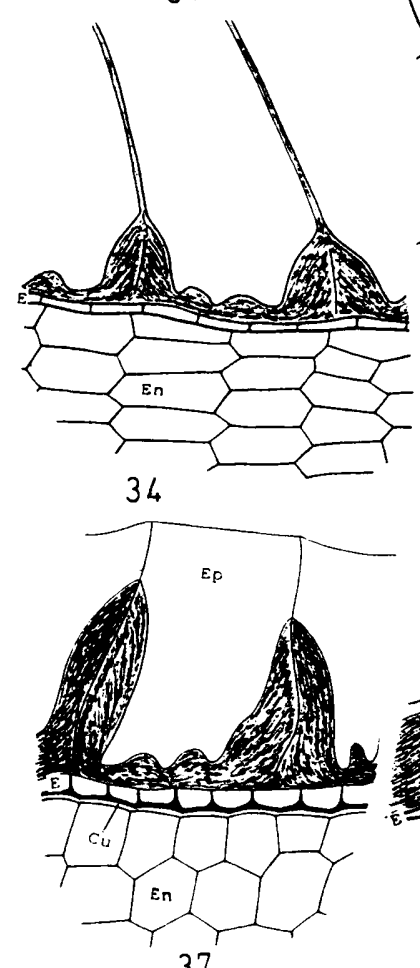

37

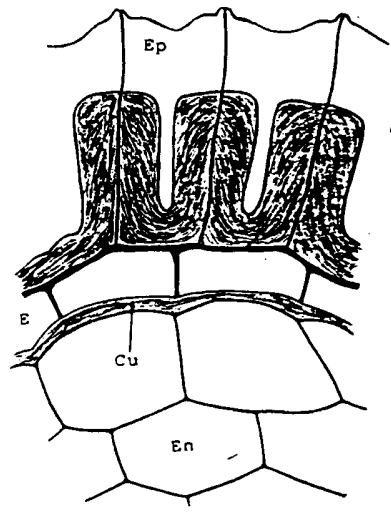

32
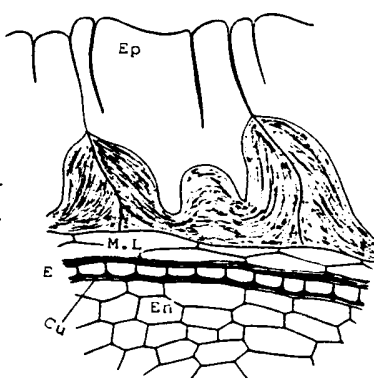

35

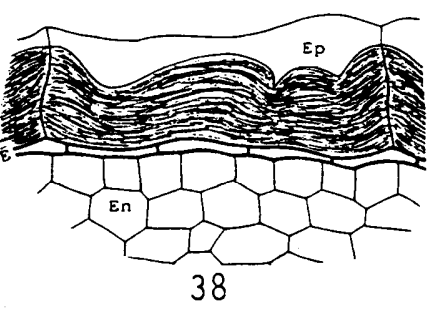

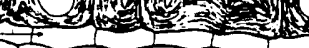

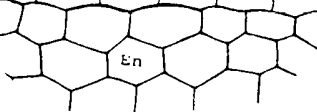

39

Plate 3- Spermoderm anatomy (continued). Fig.31. S. melongena cvs., Fig.32. S. nigrum, Fig.33. S. quitoensis, Fig.34. S. seaforthianum, Fig.35. S. sisymbriifolium, Fig.36. S. villosum, Fig.37. S. wrightii, Fig.38. Withania riebeckii, Fig.39. W. somnifera. Cu=Cuticle; $\mathrm{E}=$ Endosperm; $\mathrm{En}=$ Endothelium; Ep=Epidermis; M.L=Middle Layer. $=$ 
Table (2) The Anatomical Aspects of the Spermoderm

\begin{tabular}{|c|c|c|c|c|c|c|c|c|c|}
\hline \multirow{3}{*}{ Aspects } & \multicolumn{4}{|c|}{ Outer Epidermal Cells } & \multicolumn{2}{|c|}{ Middle Layer } & \multicolumn{3}{|c|}{ Inner Epidermis (Endothelium) } \\
\hline & \multirow[b]{2}{*}{ Shape } & \multicolumn{3}{|c|}{ Wall Thickening } & \multirow[b]{2}{*}{$\begin{array}{c}\text { Outer } \\
\text { Hypodermal }\end{array}$} & \multirow[b]{2}{*}{$\begin{array}{c}\text { Inner } \\
\text { Hyaline }\end{array}$} & \multirow[b]{2}{*}{ Shape } & \multirow[b]{2}{*}{ Thickness } & \multirow[b]{2}{*}{ Pigment } \\
\hline & & $\begin{array}{c}\text { Outer } \\
\text { periclinal }\end{array}$ & $\begin{array}{c}\text { Inner } \\
\text { periclinal }\end{array}$ & $\begin{array}{c}\text { Radial } \\
\text { wall }\end{array}$ & & & & & \\
\hline 1- Atropa belladonna L. & $\mathrm{T}$ & Straight/Cv & $\mathrm{K}$ & $\mathrm{K}^{3} / 4$ & + & + & $\mathrm{T}$ & $\mathrm{K}$ & + \\
\hline 2- A. belladonna var. lutea Doll. & $\mathrm{R}$ & Straight & $\mathrm{K}$ & $\mathrm{K}^{3} / 4$ & + & + & $\mathrm{T}$ & $\mathrm{K}$ & + \\
\hline 3- Capsicum annuum L. & $\mathrm{R}$ & Straight & K-papillose & $\mathrm{K} 3 / 4$ & + & + & Rectangular & $\mathrm{N}$ & - \\
\hline $\begin{array}{l}\text { 4- C. frutescens L. cv. California } \\
\text { Wonder. }\end{array}$ & $\mathrm{R}$ & Straight & K-papillose & $\mathrm{K} 3 / 4$ & + & + & $\mathrm{T}$ & $\mathrm{K}$ & + \\
\hline 5- C. frutescens 1. cv. Early Jalpino. & $\mathrm{R}$ & Straight & K-papillose & $\mathrm{K}^{3} / 4$ & + & + & Rectangular & $\mathrm{K}$ & + \\
\hline 6- C. frutescens L. cv. Elpaso & $\mathrm{R}$ & Straight & K-papillose & $\mathrm{K}^{3} / 4$ & + & + & Spuare & $\mathrm{K}$ & + \\
\hline $\begin{array}{l}\text { 7- C. frutescens L. cv. Long Red } \\
\text { Cayenne. }\end{array}$ & $\mathrm{R}$ & Straight & K-papillose & $\mathrm{K}^{3 / 4}$ & + & + & Rectangular & $\mathrm{K}$ & + \\
\hline $\begin{array}{l}\text { 8- Cyphomandra betacea (Cav.) } \\
\text { Sendt. }\end{array}$ & * & Disintegrating & $\mathrm{K}$ & $\mathrm{KS}$ & - & - & Square & K-inner N & - \\
\hline 9- Hyoscyamus aureus L. & $\mathrm{T}$ & Straight & $\mathrm{K}$ & KS & - & - & Rectangular & $\mathrm{N}$ & + \\
\hline $\begin{array}{l}\text { 10- H. boveanus (Dun.) Asch.\& } \\
\text { Schw einf. }\end{array}$ & $\mathrm{R}$ & $\mathrm{CV}$ & $\mathrm{K}$ & $\mathrm{KS}$ & - & - & $\mathrm{T}$ & $\mathrm{K}$ & + \\
\hline 11- H. desertorum Asch. Ex Bioss. & $\mathrm{R}$ & $\mathrm{Cv}$ & K-papillose & $\mathrm{KS}$ & - & - & Rectangular & $\mathrm{K}$ & - \\
\hline $\begin{array}{l}\text { 12- H. munticus } \mathrm{L} . \\
\text { 13- H. niger L. }\end{array}$ & $\begin{array}{c}R \\
T / R\end{array}$ & $\begin{array}{c}\text { Straight } \\
\text { Straight } / \mathrm{CV}\end{array}$ & $\begin{array}{l}\mathrm{K} \\
\mathrm{K}\end{array}$ & $\begin{array}{l}\mathrm{KS} \\
\mathrm{KS}\end{array}$ & $\begin{array}{l}- \\
-\end{array}$ & $\begin{array}{ll}- \\
-\end{array}$ & $\begin{array}{l}\mathrm{T} \\
\mathrm{T}\end{array}$ & $\begin{array}{l}\mathrm{K} \\
\mathrm{K}\end{array}$ & $\begin{array}{l}+ \\
+\end{array}$ \\
\hline 14- Lycium chinense Mill. & $\mathrm{R}$ & Deeply Cv & K-papillose & $\mathrm{KS}$ & - & - & Rectangular & $\mathrm{N}$ & + \\
\hline 15-L. shawii Roem. Et Sch. & $\mathrm{R}$ & Deeply CV & K-papillose & KS & - & - & Rectangular & $\mathrm{K}$ & + \\
\hline 16- Lycopersicon esculentum Mill. & $*$ & Disint. & $\mathrm{K}$ & $\mathrm{KS}$ & - & + & Rectangular & $\mathrm{N}$ & + \\
\hline 17- L. esculentum cv. Bakmor B. & * & Disint. & $\mathrm{K}$ & KS & - & + & Rectangular & $\mathrm{N}$ & + \\
\hline 18- L. esculentum cv. Strain B. & * & Disint. & $\mathrm{K}$ & KS & - & + & Rectangular & $\mathrm{N}$ & + \\
\hline 19- L. esculentum cv. UC 82. & $*$ & Disint. & $\mathrm{K}$ & $\mathrm{KS}$ & - & + & Rectangular & $\mathrm{N}$ & + \\
\hline 20- L. esculentum cv. VFN 8. & * & Disint. & $\mathrm{K}$ & KS & - & + & Rectangular & $\mathrm{N}$ & + \\
\hline $\begin{array}{l}\text { 21- L. esculentum var. pyriforme } \\
\text { Alef. }\end{array}$ & $*$ & Disint. & $\mathrm{K}$ & $\mathrm{KS}$ & - & + & Rectangular & $\mathrm{N}$ & + \\
\hline 22- Mandragora officinarum L. & $\mathrm{R}$ & $\mathrm{CV}$ & $\mathrm{K}$ & $\mathrm{KS}$ & - & + & - & - & - \\
\hline 23- Physalis alkekengi L. & $\mathrm{T}$ & Straight & K-papillose & KS & + & + & Square & $\mathrm{N}$ & - \\
\hline 24- P. angulata $\mathrm{L}$. & $\mathrm{R}$ & $\mathrm{CV}$ & K-papillose & $\mathrm{KS}$ & - & + & Rectangular & $\mathrm{N}$ & - \\
\hline 25-P. ixocarpa Brot. ex Hornem. & $\mathrm{R}$ & $\mathrm{CV}$ & K-papillose & $\mathrm{KS}$ & - & + & Square & $\mathrm{N}$ & - \\
\hline 26-P. peraviana L. & $\mathrm{T}$ & Straight & K-papillose & $\mathrm{KS}$ & - & + & Rectangular & K-outer N & - \\
\hline 27-P. prainosa L. & $\mathrm{T} / \mathrm{R}$ & Straight & K-papillose & KS & - & + & Rectangular & $\mathrm{K}$ & - \\
\hline $\begin{array}{l}\text { 28- Scopalia lurida(Link\&Otto.) } \\
\text { Dun. }\end{array}$ & $\mathrm{R}$ & Straight & K-papillose & $\mathrm{K} 3 / 4$ & + & + & - & - & - \\
\hline 29-S. physaloides Dun in DC. & $\mathrm{T}$ & Straight & $\mathrm{K}$ & $\mathrm{K}^{3} / 4$ & + & + & - & - & - \\
\hline 30- Solanum aviculareG.Farster. & $\mathrm{T}$ & Straight & $\mathrm{K}$ & $\mathrm{K}^{3} / 4$ & + & + & Square & K-outer N & - \\
\hline 31-S. citrullifolium A.Br. & $\mathrm{T} / \mathrm{R}$ & Straight $/ \mathrm{Cv}$ & K-papillose & $\mathrm{K}^{3} / 4$ & - & - & Rectangular & $\mathrm{K}$ & + \\
\hline 32-S. cornutum Lam. & $\mathrm{R}$ & Straight & $\mathrm{K}$ & $\mathrm{K}^{3} / 4$ & - & - & Rectangular & K-inner N & + \\
\hline 33-S. dulcamara L. & $\mathrm{T} / \mathrm{R}$ & Straight & K-papillose & $\mathrm{KS}$ & - & + & Square & K-outer N & - \\
\hline 34 S. forsskaolii Ky ex Dun. & $\mathrm{R}$ & Straight & $\mathrm{K}$ & $\mathrm{K}^{3} / 4$ & - & - & Rectangular & K-inner N & - \\
\hline 35-S. incanum L. & $\mathrm{R}$ & Straight & $\mathrm{K}$ & $\mathrm{K}^{3} / 4$ & - & - & Rectangular & $\mathrm{N}$ & - \\
\hline 36- S. indicum var. aldabranse Linn. & $\mathrm{R}$ & Straight & K-papillose & $\mathrm{K}^{3} / 4$ & - & + & Square & K-outer N & - \\
\hline 37- S. macranthum Dun. & $\mathrm{R}$ & Straight & K-papillose & $\mathrm{K}^{3} / 4$ & - & - & Rectangular & $\mathrm{K}$ & - \\
\hline 38-S. macrocarpon L. & $\mathrm{T} / \mathrm{R}$ & Straight & $\mathrm{K}$ & $\mathrm{KS}$ & - & - & Rectangular & K-outer N & - \\
\hline $\begin{array}{l}\text { 39- S. melongena L. cv. Block } \\
\text { Beuty. }\end{array}$ & $\mathrm{R}$ & Invaginated & $\mathrm{K}$ & $\mathrm{K}^{3} / 4$ & - & - & Rectangular & K-inner N & + \\
\hline 40- S. melongena cv.Long Parple. & $\mathrm{R}$ & Invaginated & $\mathrm{K}$ & $\mathrm{K}^{3} / 4$ & - & - & Rectangular & K-inner N & + \\
\hline 41-S. melongena $\mathrm{cv}$. Long White & $\mathrm{R}$ & Invaginated & $\mathrm{K}$ & $\mathrm{K}^{3 / 4}$ & - & - & Rectangular & K-inner N & + \\
\hline
\end{tabular}




\begin{tabular}{|c|c|c|c|c|c|c|c|c|c|}
\hline TL- N. Ingto & $\mathrm{R}$ & Straight/CV & $\mathrm{K}$ & $\mathrm{K}^{1 / 2}$ & - & - & Rectangular & K-inner N & - \\
\hline 43-S. quitoensis Lam. & $\mathrm{T}$ & Straight/Cv & $\mathrm{N}$ & $\mathrm{K} 1 / 2$ & - & - & Square & K-inner N & - \\
\hline 44-S. seaforthianum Andrews & $*$ & Disint. & K-papillose & $\mathrm{KS}$ & - & - & $\mathrm{T}$ & $\mathrm{K}$ & - \\
\hline 45- S. sisymbriifolium Lam. & $\mathrm{R}$ & Papillated & K-papillose & $\mathrm{K} 1 / 2$ & + & + & Rectangular & K-outer $\mathrm{N}$ & - \\
\hline 46- S. villosum (L.) Mill. & $\mathrm{R}$ & Straight & $\mathrm{K}$ & $\mathrm{K} 1 / 2$ & - & - & Rectangular & K-outer N & - \\
\hline 47-S. wrightii Benth. & $\mathrm{R}$ & Straight & K-papillose & $\mathrm{K} 3 / 4$ & - & - & Rectangular & K-outer N & - \\
\hline 48- Withania riebeckii Schweinf. & $\mathrm{T}$ & Straight & K-papillose & $\mathrm{K} 3 / 4$ & - & - & $\mathrm{T}$ & $\mathrm{K}$ & - \\
\hline 49- W. somnifera (L.) Dun. & $\mathrm{R}$ & Straight & K-papillose & $\mathrm{K}^{3} / 4$ & - & - & Rectangular & $\mathrm{N}$ & - \\
\hline
\end{tabular}

$\mathrm{Cv}$, Concave; Disint, Disintegrating; K, Thick; KS , Thickness to the summit; K $3 / 4$, Thickness

almost $3 / 4 ; \mathrm{k} \frac{1}{2}$, Thickness almost to the middle; $\mathrm{N}$, Thin ; R, Radially elongated ; $\mathrm{T}$, Tangentially

elongated ; +, Present ; -, Absent; •, Foreign taxa.

Of all the characters of the endothelium the universality of thickening on its walls and the presence of pigments are found to be fairly diagnostic at the generic level. In Atropa species it is pigmented and the thickenings are deposited on all the walls. In Lycopersicon species it is also pigmented but all the walls are thin.

\section{Conclusions}

In addition to the identificatory key suggested for the studied taxa, the subsequent salient remarks on the taxonomy and the phylogeny of Solaneae are presented.

From the taxonomic view point the shape of the seed is found to be an exclusive character for certain taxa. These are Lycopersicon species where the seed is oval and provided with long tubular 'hairs' and Capsicum species where it is reniform with tapering ends. Except for the genera Solanum, Physalis, Atropa and Lycium, the hilar characteristics are uniform within the remainder examined taxa.

The aspect of the anticlinal walls (undulation, thickening and detection of the primary cell wall) as clarified by SEM showed consistency at the infraspecific level (cvs. of Lycopersicon esculentum and Capsicum frutescens). Where present, the different aspects of the outer periclinal wall are consistent at the generic level (Solanum excluded).

Of the anatomical remarks, the extent of deposition of thickening on the radial walls was consistent at the generic level (Solanum excluded).

As regards the purity of the genera, the consistency of the morphological characters in the studied species of Lycopersicon, Lycium, Hyoscyamus, Physalis and Withania is an indicator to the homogenity of these genera, whereas the diversity of the same characters in Solanum species renders it a heterogeneous one.

However, the totality of the morphological and anatomical data culminated into some taxonomic and nomenclatural changes.In terms of Wettstein's classification (Table 3) the subsequent taxonomic changes are suggested. 
A. S. Al-Nowaihi and M. M. Mourad

Table (3): Part of Wettstein's classification of the tribe Solaneae (1895)

\begin{tabular}{|c|c|c|c|c|}
\hline Tribe & Subtribe & Genera & Section & Species \\
\hline \multirow[t]{16}{*}{ Solaneae } & Lyciinae & Atropa & & \\
\hline & & Lycium & Brachycope & L.europaeum, L.arabicum \\
\hline & & & Mesocope & \\
\hline & & & Macrocope & \\
\hline & Hyoscyaminae & Scopolia & Euscopolia & \\
\hline & & & Anisodus & S. lurida \\
\hline & & Hyoscyamus & Euhyoscyamus & H. muticus, H. niger, H. albus, H. aureus \\
\hline & & & Chlamaehyoscyamus & \\
\hline & Solaninae & Withania & & W. riebeckii, $W$. somnifera \\
\hline & & Physalis & Eucansicum & $P$. alkekengi, $P$. ciliata, $P$. peruviana \\
\hline & & Capsicum & $\begin{array}{l}\text { Eucapsicum } \\
\text { Tubocapsicum }\end{array}$ & С. cannum, c. Jrutescens. \\
\hline & & Solanum & $\begin{array}{l}\text { Pachystemonum } \\
\text { Lycianthus }\end{array}$ & S. dulcamara, S. nigrum, S. villosum \\
\hline & & & Leptostemonum & S. melongena \\
\hline & & & $\begin{array}{l}\text { Lycopersicon } \\
\text { Nycterium }\end{array}$ & S. Lycopersicon, S. Pyriforme \\
\hline & Mandragorinae & Cyphomandra & & C. betacea \\
\hline & & Mandragora & & M. officinarum \\
\hline
\end{tabular}

\section{1- Transference (Re-allocation)}

Hyoscyamus muticus is better transferred from section Euhyoscyamus Wettstein to section Chlamaehyoscyamus Wettstein; the latter section contains in addition, H. aureus. This may be justified by the sharing of the seed of both species to many morphological characters as well as their keying out.

\section{2- Addition:}

a- Scopolia physaloides, not mentioned by Wettstein, is added with S. lurida in section Anisodus.

b- Solanum incanum is added with $S$. melongena in section Leptostemonum.

c- Physalis ixocarpa and P. pruinosa were neither mentioned by Wettstein nor assigned to any section. Here, both species are added in the proposed classification, and assigned to two new sections:

i) Section Angulata containing $P$. angulata

ii) Section Peruviana containing $P$. alkekengi, $P$. ixocarpa, $P$. pruinosa and $P$. peruviana.

With regard to the nomenclatural changes, the following amendments are suggested:

i) The old name Solanum bactaceum Cav. is retained over Cyphomandra bactacea Sendt. This is favoured by the pronounced similarity in the morphology and anatomy of the spermoderm of both Solanum seaforthianum and Cyphomandra batacea which led to 
their keying together, as well as being attached with most Solanum species as presented in the lay-out of the phylogenetic status.

ii) Solanum villosum (L.) Lam. is lowered to the variety rank as suggested early by Linnaeus (1753); thus amended to Solanum nigrum var. villosum L. An external evidence comes from the work of Wojciechowska (1972) who stated that S. nigrum and $S$. villosum were keyed together.

iii) The variety lutea of Atropa belladonna is raised to the specific rank A. lutea AlNowaihi \& Mourad stat. nov. Table (4) shows the amendments suggested for Wettstein's classification.

Table (4) Proposed modifications to Wettstein's classification of the tribe Solaneae

\begin{tabular}{|c|c|c|c|c|}
\hline TRIBE & SUBTRIBE & GENERA & SECTION & SPECIES \\
\hline \multirow{21}{*}{ Solaneae } & \multirow[t]{4}{*}{ Lyciinae } & Atropa & & A. belladona*, A. lutea! \\
\hline & & Lycium & Barchycope & L.shawii, L.chinense* \\
\hline & & & Mesocope & \\
\hline & & & Mesocope & \\
\hline & \multirow[t]{5}{*}{ Hyoscyaminae } & Scopolia & Euscopolia & \\
\hline & & & Snisodus & S. lurida, S.physaloides* \\
\hline & & Hyocsyamus & Euhyoscyamus & H.albus, H. niger, \\
\hline & & & & H.boveanus* \\
\hline & & & Chlamaehyoscyamus & H, aureus, ${ }^{\circ}$ H.muticus ${ }^{\circ}$ \\
\hline & \multirow[t]{10}{*}{ Solaninae } & Withania & & W.riebeckii, W.somnifera \\
\hline & & Physalis & Angulata• & $P$. angulata. \\
\hline & & & Peruviana• & $\begin{array}{l}\text { P.alkekengi, } P . \text { peruviana, } \\
\text { P.pruinosa*, } P . \text { ixocarpa } *\end{array}$ \\
\hline & & Capsicum & Eucapsicum & C. annuum, C. frutescens. \\
\hline & & & Tubocapicum & \\
\hline & & Solanum & $\begin{array}{l}\text { Pachystemonum } \\
\text { Lycianthus }\end{array}$ & S.dulcamara, S. nigrum \\
\hline & & & Lepostemonum & S. melongena, S. ncanum* \\
\hline & & & Nycterium & $\begin{array}{l}\text { S. citrullifolium, } \\
\text { S. macrocarpon }\end{array}$ \\
\hline & & & & $\begin{array}{l}\text { Solanums *spp. No. } 30,31,33,35 \text {, } \\
36,37,34,44,45 \text { and } 47\end{array}$ \\
\hline & & Lycopersicon & & L. esculentum \\
\hline & \multirow[t]{2}{*}{ Mandragorinae } & Cyphomandra & & C. betacea ф \\
\hline & & Mandragora & & M.officinarum \\
\hline
\end{tabular}

- New sections proposed; * Taxa not mentioned by Wettstein; $\phi$ Taxa amended; ! New Species; 
o Taxa transferred to new section

As regards the phylogenetic status of the studied taxa Corner (1976) and Prasad $\&$ Singh (1978) relied upon the number of the spermoderm layers as an indicator to the evolutionary status. They considered the multilayered seed coat is less advanced than the few-layered one. Following the same concept the studied taxa are arranged from less advanced to more advanced as shown in Fig. (1). The less advanced multil -layered taxa are Solanum aviculare, S. sisymbriifolium, Atropa, Capsicum, Mandragora and Scopolia. In these taxa the three layers are present with the middle layer differentiated into a hyaline zone and a hypoderm. The more advanced few-layered taxa are Cyphomandra, Hyoscyamus, Withania, Lycium and some Solanum species. In these taxa the middle layer is absent altogether. Intermediate taxa are those in which the middle layer of the seed coat is represented by the hyaline zone while the hypodermal zone is absent. These taxa are Solanum dulcamara, S indicum var. aldabranse, Lycopersicon and Physalis.

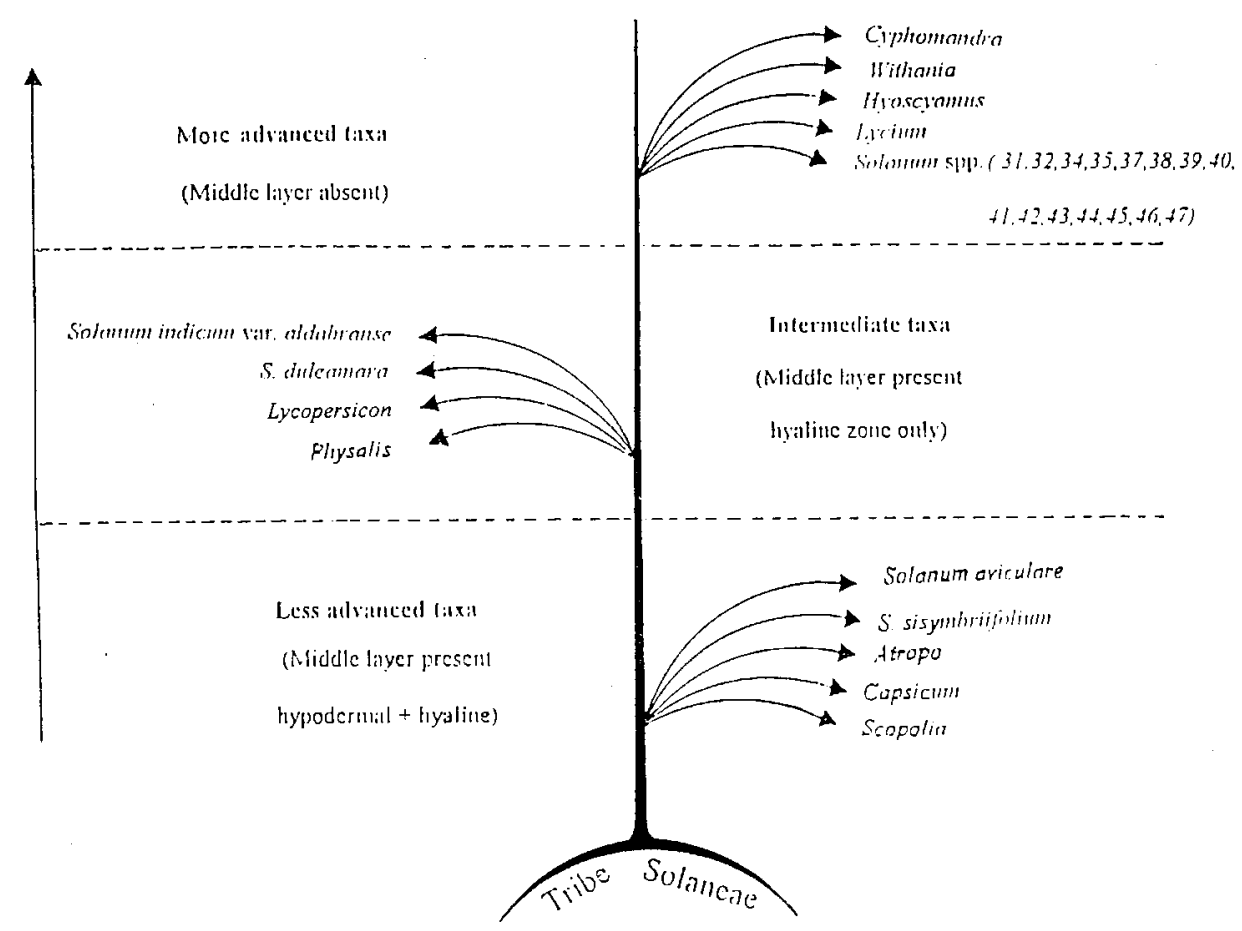

Fig. (1) A proposed phylogenetic status for the studied taxa of tribe Solaneae 


\section{key for the studied taxa of the tribe Solaneae}

A. Hilum at a level

B. Seeds covered with hairs

C. Anticlinal walls lobed

Lycopersiconesculentum cvs.

CC. Anticlinal walls slightly undulate .... Lycopersicon esculentum var pyriforme. BB. Seeds glabrous

D. Anticlinal walls straight (s.v)

E. Seeds pear to reniform

Scopolia physaloides

EE. Seeds subglobose Atropa lutea

DD.Anticlinal walls lobed (s.v)

F. Thin Solanum wrightii

FF. Thick

G. Hilum aperture slit-like.

H. Seeds oval, anticlinal wall micropapillate.

I. Endothelial cells square, middle layer of hyaline zone only, inner tangential wall of outer epidermis with papillate thickening Solanum ulcamara.

II. Endothelial cells rectangular, both middle layer and papillose thickening lacking

Solanum nigrum \& S. nigrum. var. villosum

HH. Seeds reniform, anticlinal wall smooth, intestine like

GG. Hilum aperture rounded

Physalis angulata.

J. Seeds oval

K. Primary walls detectable (persistent)

L. Endothelial cells thin, rectangular ....... Hyoscyamus aureus.

LL Endothelial cells thick, tangentially flattened

Hyoscyamus muticus.

KK. Primary walls undetectable

M Inner tangential wall of the epidermis with papillose thickening, endothelial cells rectangular

Hyoscyamus desertorum.

MM. Inner tangential wall of the epidermis without papillose thickening, endothelial cells tangentially flattened

JJ. Seeds pear to reniform.

Hyoscyamus boveanus \& H. niger.

N. Two zones of middle layer persistent, radial wall thichening to

$3 / 4$ of its length

Scopolia lurida.

NN. Only hyaline zone of the middle layer persistent, radial wall thickening to the summit Physalis peruviana.

JJJ. Seeds orbicular Lycium chinense.

AA. Hilum sunken

O. with the surrounding epidermal cells arched (ridged).

P. Hilum rounded

PP. Hilum slit-like.

Mandragora officinarum. 
Q. Anticlinal walls lobed, micropapillate

Capsicum annuum.

QQ. The same slightly undulate, smooth Capsicum frutescens cvs.

OO. With the surrounding epidermal cells at a level

R. Hilum slit-like.

S. Anticlinal walls straight, papillate

Solanum quitoensis.

SS. Anticlinal walls lobed, micropapillate

T. Endothelial cells thick, square .....Solanum indicum var. aldabranse.

TT. Endothelial cells thin, rectangular Withania somnifera.

SSS. Anticlinal walls lobed, smooth Withania riebeckii

RR. Hilum rounded

U. Seeds 'hairy'

- Seeds reniform

Solanum seaforthianum

$=$ Seeds orbicular Solanum betaceum

UU. Seeds glabrous.

V. Primary wall detectable (persistent)

$1 \mathrm{~W}$. Seeds renifrom.

- Endothelial cells thin, square

Physalis alkekengi \& P. ixocarpa

= Endothelial cells thick, rectangular...... Physalis pruinosa

$2 \mathrm{~W}$. Seeds orbicular

Solanum macranthum

$3 \mathrm{~W}$. Seeds oval Solanum citrulliflolium

VV. Primary wall undetectable

$1 \mathrm{X}$. Anticlinal walls lobed, smooth

- Seeds triangular

Lycium shawii.

$=$ Seeds oval Solanum aviculare.

$2 \mathrm{X}$. Anticlinal walls straight.

- Wall smooth

Solanum forsskaolii

$=$ Wall micropapillated Solanum sisymbriifolium.

3 X. Anticlinal walls lobed, intestine-like

Y. Seeds pear-like

Solanum macrocarpon YY. Seeds orbicular to reniform

- Endothelial cells thick, pigmented

$=$ Endothelial cells thin, not pigmented

Solanum melongena cvs.

Solanum incanum

4 X. Anticlinal walls lobed,micropapillate

Solanum cornutum.

AAA. Hilum elevated Atropa belladonna.

\section{Acknowledgement}

We thank Hortus Botanicus Nationalis Belgii, the Herbarium of the Royal Garden, Kew and Botanischer Garten Der universitat, Zurich for providing the seeds of the foreign taxa.

\section{References}


Al-Nowaihi, A.S Khalifa, S.F. 1974. A numerical classification of Solanaceae in Egypt. Ind. Bot. Soc. 53:224-248.

Barthlott, W. 1981. Epidermal and seed surface characters of plants: Systematic applicability and some evolutionary aspects. Nord. J.Bot. 1:345-355.

1984. Microstructural features of seed surfaces. In Current Concepts in Plant Taxonomy. (eds. V.H. Heywood \& D. M. Moore): 95-105. London: Academic Press.

Corner, E.J.H. 1976. The Seeds of Dicotyledons I. Cambridge, U.K.

Czaja, A.T.H. 1963. Neue Untersuchungen an der Testa der Tomatensamen. Planta, 59: 262-279.

Dilcher, D.L.1974. Approaches to the identification of angiosperm leaf remains. Bot. Rev. 40:1-157.

Dnyansagar V.R.\& Cooper, D.C. 1960. Development of the seed of Solanum phyreja. Am. J. Bot. 47:167-186.

Edmonds, J. M. 1983. Seed coat structure and development in Solanum L. section Solanum (Solanaceae). Bot. J. Linn. Soc. 87 (3): 229-246.

Forooqui, S. M. 1983. Seed morphology of a Nicotiana species Nicotiana Kowakamii (Solanaceae). Indian J. Bot. 6 (1): 98-99.

. \& Bahadur, B. 1984. Seed characters LM and SEM in 3 species of Nicotiana L.. Indian Bot. Rep. 3 (1): 92-94. 1985. Studies on seed morphology LM and SEM of American Nicotiana L. (Solanaceae). Indian J. Bot. 8 (2): 191-197.

Gunn, C.R. \& Gaffney, F.B. 1974. Seed characters of 42 economically important species of Solanaceae in United States; U. S. D.A. Technical Bulletin 1471:-1-3.

Hayward,H.E. 1938. The structure of economic plants. New York: The Macmillan Company.

Henderson, R J.F. 1974 Solanum nigrum L. (Solanaceae) and related species in Australia. Contributions from the Queensland Herbarium, 16:1-78.

Isely, D. 1947. Investigations in seed classification by family characteristic. Iowa Agricultural Experiment Station, 28, Agricultural Research Bulletin, 351:317-380.

Jha, S.S.\& Pondey, A. K. 1989. Seed coat structure in Melilotus (Fabaceae). Phytomorphogy, $39(\mathbf{2 , 3})$ : 221-229.

Johansen D.A. 1940.Plant Microtechnique, (New York: Mc Graw-Hill).

Linnaeus. C.1753. Species Plantarum ed. 1. (Stockholm). 
Martin, A. C. \& Barkley, W.D. 1961. Seed Identification Manual. University of Califronia Press, Perkeley, U.S.A.

Mohan, K. 1970. Morphological studies in Solanceae. V. Embryology as well as structure and development of seed of Solanum macranthum Dun. Agra. University J. of Research (Science), 19:55-66.

Prasad, T. \&Singh, D. 1978. Gametophytes and seed development in Nicotiana physaloides. J. Indian Bot. Soc. 7-5(1): 76-83.

Preisner, T.R.1985. A preliminary light and scanning electron microscope study on the seed coat of six varieties of Lycopersicon esculentum. Proc. Pa. Acad. Sci. 59(1) :83.

Rick, C. M. 1978. The Tomats. Scientific American. 239: 67-76.

Saxena, T. \&. Singh, D. 1969. Embryology and seed development of tetraploid form of Solanum nigrum. Linn. J. Ind. Bot. 48:148-157.

Sharma, S.K; Babu, C.R.; Johri, B.M. \& Hepworth, A. 1977. SEM studies on seed coat patterns in Phaseolus mungo radiatus-subloatus complex. Phytomorphology 27:166-111.

Souégés, R.1907. Development et structure du tegument seminal chez les Solanaceae. Sci Ann.. not. Bot.. Ser. 9:1-124.

West, T. 1866. On the structure of the testa of the seed of Solanaceae. J.Bot. 4: 208.

Wettstein, R.1895. Solanaceae in Engler und Prantl. Die naturalichen pflanzenfamitien IV Abt. 3-b :4-38. Leipzing, Wilhelm Engelman.

Whalen, M.D.1979 a. Speciation in Solanum Section Androceras, in J. G. Hawkes et al. (eds). The Biology and Taxonomy of the Solanaceae: 581-596- London: Academic Press.

..1979 b. Taxonomy of Solanum section Androceras. Gentes Herbarium 11: $359-426$.

Wilkinson, H.P 1980. The Plant surface, in Anatomy of the dicotyledons, (eds. C.R. Metcalfe \& L. Chalk): 97-165. London: Oxford Press .

Wojciechowska, B.1971. Diagnostic features of Solanum aviculare Forst. and S. laciniatum Ait. Seed. Herb. Polonica 17:31-39.

Wojciechowska, B. 1972. Systematic studies on the seeds of the family Solanceae Pers . Monographic Botancia. 36: 117-197 